\title{
Applying the Principles of UDL in College English Teaching
}

\author{
Yinfeng Guan*
}

\author{
Southwest University, Chongqing, China \\ ${ }^{*}$ Corresponding author. Email: 529447303@qq.com
}

\begin{abstract}
With the enrollment expansion in higher education, more and more students with diverse learning needs and abilities flood into the university, which gives a lot more challenges to college English teachers. How to teach English effectively to such a big number of students with diverse background information is an urgent problem that each English teacher needs to solve. Universal Design for Learning (UDL) is one potential solution, for its final aim is to make learning accessible to all the students. The application of UDL in English teaching provides teachers with new insights from the viewpoint of learning to face the problem of diversity and makes them help each student to achieve their full potential. This paper attempts to elaborate the three principles of UDL and illustrate how to apply them in practical English teaching.
\end{abstract}

Keywords: UDL, College English teaching, English learning, Accessible.

\section{THE GOALS AND CURRENT SITUATION OF COLLEGE ENGLISH TEACHING}

According to College English Curriculum Requirements[1] which was revised in 2020, the objective of college English is to develop students' ability to use English in a well-rounded way. In order to meet this requirement, teachers must understand students very well so as to know what to do and how to do in helping them improve their English. With the advancement of pedagogical theory, there is a general consensus among teachers about the need to transform their teaching perceptions from a traditional teacher-centered idea to a more scientific student-centered one. Teachers used to dominate the whole learning process in the class, playing the role of authority. What the students should do is just to follow the teachers, which surely results in their passive learning since they are deprived of the opportunities to participate, to explore and to regulate their own learning. When there is no interest in English learning, how can the students have a better capability to use English? Guided by the student-centered concept, when preparing a class, teachers are prompted to design the teaching process from the perspective of the students learning instead of their own teaching. In class, they inspire the students to engage in the class activities and facilitate their leanings by just playing leading roles.

Based on the transformation of the perception on teaching, a lot of reforms on teaching approaches have been initiated, such as the adoption of PBL (project-based learning), TBL (task-based learning), CLA(cooperative learning approach) and IBL(inquiry-based learning). To some degree, these reform attempts have produced a lot of good effects in developing students' ability to use English. However, those approaches mentioned above neglect a fact that each student is unique and that there is a rapidly increasing range of academic diversity in higher education[2]. With the increasing enrollment of college these years, students from diverse backgrounds flood into the campus, the conflict intensifies between one fit-for-all approach and students with diverse English learning experiences. Thus, a new problem is emerging on how to maximize the potential of each student and make them benefit from their own English learning. Universal Design for Learning(UDL), the core concept of which is to make each learner get access to learning, is a potential solution to this problem. This article details the three principles of UDL and discusses their practical applications on the college English teaching, trying to meet the needs of all students and to meet the College English Curriculum Requirements as well. 


\section{LITERATURE REVIEW OF UDL}

Universal Design for Learning (UDL) was originated from Universal Design (UD), a term used in the field of architecture which aims to bring disabled people convenience by providing barrier-free design in construction. Then, at the beginning of the twenty-first century, the concept of an accessible design to all users was spread to educational field. In 1980s in America, the association of CAST(Center For Applied Special Technology) extended the idea of access to the learning environment by using Universal Design for Learning to address the needs of disabled students[3]. Later on, the idea of UDL has been applied to all the learners to meet Table 1. Universal Design for Learning their different needs. In order for more people to deeply understand UDL, CAST summarizes three principles to this approach: (1) multiple means of representation; (2) multiple means of action and expression and (3) multiple means of engagement.[2] Under each principle, there are three guidelines that explains the specific ways on how to use these principles in teaching. Teachers do not need to cover all the guidelines in one given class, instead, they are free to choose one or more according to their own realistic needs on teaching. The ultimate aim of this approach is to create expert learners in learning with motivation, purpose, strategy and knowledge, who take command of their own learning.[4] (see Table 1)

\begin{tabular}{|c|c|c|}
\hline \multirow{3}{*}{$\begin{array}{l}\text { multiple means of } \\
\text { representation }\end{array}$} & a.provide options for perception & \multirow{3}{*}{$\begin{array}{l}\text { Resourceful,knowledgeable } \\
\text { learners }\end{array}$} \\
\hline & $\begin{array}{l}\text { b.provide options for language, mathematical expressions } \\
\text { and symbols }\end{array}$ & \\
\hline & c.provide options for comprehension & \\
\hline \multirow{3}{*}{$\begin{array}{l}\text { multiple means of } \\
\text { action and expression }\end{array}$} & a.provide options for physical action & \multirow{3}{*}{$\begin{array}{l}\text { Strategic, } \\
\text { learners }\end{array}$} \\
\hline & b.provide options for expression and communication & \\
\hline & c.provide options for executive functions & \\
\hline \multirow{3}{*}{$\begin{array}{l}\text { multiple means of } \\
\text { engagement }\end{array}$} & a.provide options for recruiting interest & \multirow{3}{*}{ Purposeful, motivated learners } \\
\hline & b.provide options for sustaining efforts and persistence & \\
\hline & c.provide options for self-regulation & \\
\hline
\end{tabular}

It can be easily seen from the table that the key words in these principles are "multiple, options". Actually, the core tenet of UDL is to provide options for students to select according to their own learning needs, the result of which is to get every learner have access to learning. This brings teachers not only challenges but also new insights on teaching. For teachers, when designing teaching, it is better for them to reflect from the perspective of students learning. By taking into consideration of the students' individuality and characteristics, it breaks through the tradition that all students share the same set of teaching modes and criterion. When teachers satisfy the unique need of each learner through flexible and varied instruction, they offer more opportunities for those who are slow in learning, and make more students enjoy the fun of gaining knowledge and skills.

The UDL goals of developing expert learners remind us that, as English teachers, it is more important for us to guide and cultivate the students to be good learners than just to impart knowledge. We not only strive to help students master English knowledge and ability, but also help them learn how to learn, how to become proficient and independent learners. When we design class teaching, it is of great help for us teachers to take into consideration the three principles of UDL.

\section{APPLYING THE PRINCIPLES OF UDL IN COLLEGE ENGLISH TEACHING}

With the development of educational technology, college English teachers are likely to get access to abundant resources both online and off-line, which makes it possible to apply the principles of UDL to English teaching. Moreover, the challenge of meeting the needs of a growing number of diverse students in today's college classrooms that English teachers have to confront makes it quite necessary to put into practice those principles of UDL so as to ensure each learner has gained something on the way of English learning.

\subsection{Multiple Means of Representation}

Multiple means of representation refers to the ways that teachers provide to the students to acquire information and knowledge. Actually, this first principle emphasizes providing comprehensible input for students. Teachers can meet this principle by giving options on course materials and adjusting their instructional strategies. For example, in teaching, they can share the course materials in various ways, like in paper book or in e-book or in audio version. These different ways of representation provide options for students to choose according to their own preferences and ensures all course materials are accessible to each student. In the meanwhile, teachers can provide multiple means of input by using internet resources, stimulating the students' learning interests by presenting videos, pictures, stories, speeches...In this way, the learning barriers that the forms of the materials bring would be reduced and the students' learning enthusiasm would be inspired. Secondly, since college students varied in their English levels, some are quite good at it while others are poor in it, it is good for students to have a better 
understanding if the teacher speaks some Chinese in class, especially when they give some instructions or analyze the grammars. Last but not least, the teacher can meet this principle by writing specific learning outcome for each class, making sure that all the inputs are useful and effective. Furthermore, at the end of each class, both the teacher and the students can evaluate their performances by looking at the learning outcome.

\subsection{Multiple Means of Action and Expression}

Multiple means of action and expression refers to the ways of assessing the students' performances. In other words, this principle mainly deals with students' output. This principle requires teachers to offer students freedom to choose the ways to demonstrate their learned skills and knowledge. Since the students are different kinds of learners with different preferences, some love speaking English while others are very good at writing. When assessing the students' comprehension on the information and knowledge that they are required to understand, the teachers can also provide options for students to turn in their assignments, such as writing an essay or making up sentences or giving a speech, etc. The students do not have to be assessed in the same way, they are the masters of their learning. They can decide the forms of output and thus have more senses of achievement by doing it well. This principle also suggests that teachers can adopt the strategy of self-reflection at the end of each class. The use of this strategy allow instructors to know what knowledge needs to be consolidated and retaught. In the meanwhile, it makes the students be aware of their learning effect in class as well. One example is that the teacher asks the students to summarize their learning by answering the questions as "What have I gained in this class?", "What am I still puzzled at?" and "What do I want to know more?" The students may write down or answer orally these questions which surely help them become strategic and goal-oriented learners.

\subsection{Multiple Means of Engagement}

Multiple means of engagement refers to active participation of the students when they are learning in class. This principle stresses the active learning climate of the classroom that the teacher should create. In a class with thirty or even more students in English class, how to involve all the students in learning is a problem that teachers need to solve urgently. Since human is social, one effective solution is group work. By working with others, learner' interests can be aroused which definitely results in easier learning. In college English teaching, one common and effective group work is discussion. If we surf the internet, it is not difficult to find discussions both in the whole class or in small groups is very helpful for students' interaction with each other. Thus, when teachers conceive the teaching plan in class, they can increase the students' engagement by offering more opportunities for students to interact with each other. Moreover, when students discuss in class, if the teacher offer them opportunity to change their physical position, it will improve their engagement as well. Physical change can stimulate the students, making the boring class into interesting. For example, when discussing, instead of keeping sitting, the teacher can ask students to stand in circle in class or to complete some physical competition. Learning can not only happen by being confined to sitting and absorbing what the teacher lectures, it can also occur by standing and interacting with other students. Moreover, faculty can also respond to this principle through being accessible to students via email or through regular, scheduled office hours. When the students find they can be friends with the teacher or the teacher is very accountable, they will be encouraged to get involved in the class that the teacher is having.

\section{CONCLUSION}

The basic idea of UDL is to reduce barriers for learners when teachers design teaching procedure. By removing those obstacles in learning, teachers actually make learning more accessible to student learners. The three principles of UDL give English teachers new insights into teaching, enabling them to think about their tutoring holistically-from the angle of teaching and learning as well, thereby find out the possible barriers for learners. The guidelines under each principle shows the specific ways on the integration between UDL and teaching, from which teachers are able to know how to remove those blocks and increase access to English learning. The goals of producing expert learners, which conforms to the objectives of college English teaching, explain to teachers why they should adopt the approach of UDL.

Guided by UDL, college English teachers have appropriate access to the reflection on their teaching objectives, methods, means, etc.. After all, the more reflections teachers have on teaching, the more benefits the students would gain from learning. Using these principles when designing a class brings teachers a lot of benefits, it can help the teachers (1) to transform from the mindset of "teacher-centered" to "student-centered"; (2) to have holistic awareness of covering each student on the basis of their own needs and characteristics instead of those of the most students. (3) to set a clear and specific teaching goal in mind before each class and make a corresponding assessment at the end of each class; (4) to build a more inclusive climate in class which encourages more interactions between teachers and students, between students and students; (5) to learn more about the students and form a closer relationship with them; (6) to improve their senses of responsibility and achievement by making a more adequate preparation to meet the need of each student. 


\section{REFERENCES}

[1] College English Curriculum Requirements

[2] Nina Saha-Gupta, Holim Song, Reginald L. Todd, Universal design for learning (UDL) as facilitating access to higher education, Journal of Education and Social Development, 2019.

[3] Kavita Rao, Min Wook Ok, Brian R. Bryant, A review of research on universal design educational models, Remedial and Special Education, 2014.

[4] Kavita Rao, Caroline Torres, Supporting academic and affective learning processes for English language learners with universal design for learning, TESOL Quarterly, 2017. 